PRZEMYSŁAW OSIEWICZ

Poznań

\title{
Kwestia cypryjska: przebieg i konsekwencje rokowań w latach 2008-2012
}

\section{Wprowadzenie}

Kwestia cypryjska pozostaje jedynym z najdłużej trwających sporów międzynarodowych. Niemniej, między bezpośrednio zainteresowanymi stronami nie ma zgody nawet co do tego, od kiedy są w sporze. Podczas gdy strona Tureckich Cypryjczyków utrzymuje, iż spór trwa od roku 1963 roku, Greccy Cypryjczycy wskazują na rok 1974 oraz konsekwencje tureckiej interwencji zbrojnej na wyspie.

Od 2004 roku, czyli od momentu przystappienia Republiki Cypryjskiej do UE, kwestia cypryjska stała się także wewnętrznym problemem Unii Europejskiej. Co więcej, problemem, którego znaczenie trudno bagatelizować, ponieważ w praktyce od jego rozwiązania uzależniona jest ewentualna, przyszła akcesja Turcji do UE. Przeciwnicy tureckiego członkostwa już uczynili z cypryjskiego sporu argument w rokowaniach z Ankarą. W grudniu 2006 roku Rada Europejska podjęła decyzję o zamrożeniu negocjacji w ośmiu obszarach negocjacyjnych. W praktyce warunkiem ich otwarcia pozostaje nawiązanie stosunków dyplomatycznych pomiędzy Turcją a Republiką Cypryjską.

Niepowodzenie rokowań w latach 2001-2004 oraz fiasko tak zwanego planu Annana doprowadziło do ponad czteroletniej przerwy w negocjacjach cypryjskich. Wznowienie dialogu utrudniała sytuacja polityczna w greckiej części wyspy. Zmiana stała się możliwa dopiero w 2008 roku, gdy prezydentem Republiki Cypryjskiej został Dimitris Christofias. Dzięki staraniom Christofiasa oraz lidera Tureckich Cypryjczyków, Mehmeta Ali Talata, we wrześniu 2008 roku udało się zainicjować nową rundę rokowań bezpośrednich. Niniejszy artykuł stanowi analizę ich przebiegu aż do lata 2012 roku. Jednocześnie jest próbą nakreślenia scenariuszy średnioterminowych.

\section{Sytuacja polityczna Greckich Cypryjczyków po 2008 roku}

Z punktu widzenia zmian na scenie politycznej Republiki Cypryjskiej, największe znaczenie miały wybory prezydenckie przeprowadzone w lutym 2008 roku. W dużej mierze od ich wyniku zależeć miało oficjalne stanowisko Greckich Cypryjczyków. Zagraniczni analitycy wskazywali, iż wybory z 2008 roku były też swego rodzaju plebiscytem wśród zwolenników i przeciwników wznowienia rokowań bezpośrednich z Tureckimi Cypryjczykami. Głównymi kandydatami byli: urzędujący prezydent Tassos Papadopulos, Ioannis Kasulidis oraz Dimitris Christofias. Ku wielkiemu zaskoczeniu, w pierwszej turze wyborów, przeprowadzonej 17 lutego, zwyciężył Ioannis Kasulidis 
(33,51\%), który minimalnie wyprzedził Christofiasa $(33,29 \%)$. Tym samym z rywalizacji odpadł Tassos Papadopulos, który otrzymał 31,79\% głosów. W drugiej turze, 24 lutego, zwyciężył lider partii komunistycznej AKEL Dimitris Christofias (53,37\%) ${ }^{1}$. Nowy prezydent wkrótce wyznaczył nowych ministrów, a nowy gabinet rozpoczął urzędowanie już 28 lutego. Zwycięstwo Christofiasa stanowiło zapowiedź radykalnej zmiany na cypryjskiej scenie politycznej, a także stworzyło szansę na przełamanie impasu w kontaktach z przedstawicielami społeczności Tureckich Cypryjczyków. Jeszcze będąc w opozycji, Christofias utrzymywał serdeczne kontakty z liderem Tureckich Cypryjczyków Talatem. Nie oznaczało to jednak jego gotowości do daleko idących ustępstw.

W jednym z pierwszych przemówień Dimitris Christofias oświadczył: „Problem nie został rozwiązany z winy Turcji, która odmówiła przyjęcia rozwiązania korzystnego dla narodu cypryjskiego. [...] Nadszedł czas na przyjęcie rozwiązania, które będzie sprawiedliwe, funkcjonalne i możliwe do przyjęcia. Rozwiązania, które doprowadzi do przywrócenia poszanowania zasad prawa międzynarodowego. Zasad, które od czasu inwazji z 1974 roku są łamane przez Turcję, czego przejawem jest okupacja znacznej części naszej ojczyzny"2. Równocześnie, wkrótce po pierwszym spotkaniu z Talatem i decyzji o woli wznowienia rokowań, nowy prezydent wysłał pozytywny sygnał pod adresem Tureckich Cypryjczyków: „Głównymi graczami w ramach procesu są liderzy obu społeczności. Ten proces jest prowadzony w ramach Organizacji Narodów Zjednoczonych, przy asyście ze strony sekretarza generalnego i jego współpracowników. Mając w pamięci nasze traumatyczne doświadczenia ze sztywnymi ramami czasowymi i arbitrażem z 2004 roku, wysłaliśmy społeczności międzynarodowej czytelny sygnał, że w ramach nowego dialogu to liderzy obu społeczności będą pierwszoplanowymi rozmówcami. W ten sposób unikniemy powtórzenia błędów z przeszłości. Opowiadamy się za rozwiązaniem wypracowanym przez Cypryjczyków dla Cypryjczyków i społeczność międzynarodowa przyjęła to do wiadomości”’3. Wkrótce potem, 3 września 2008 roku, obaj liderzy oficjalnie zainaugurowali nową rundę negocjacji ${ }^{4}$.

\section{Społeczność Tureckich Cypryjczyków po planie Annana}

Wybory prezydenckie w nieuznawanej Tureckiej Republice Północnego Cypru są z uwagą śledzone przez społeczność międzynarodowa, w tym Greckich Cypryjczyków. Choć Republika Cypryjska konsekwentnie nie uznaje ich państwowego charakteru i odmawia tytułowania lidera społeczności tureckiej jako prezydenta, powszechnie wiadomo, że zwycięzca wyborów na północnym Cyprze pełni zarazem funkcje głównego negocjatora. Rok po fiasku inicjatywy pokojowej z 2004 roku, 17 kwietnia 2005 roku, wybory prezydenckie w TRPC wygrał Mehmet Ali Talat, urzędujący premier, zwolennik porozumienia ze społecznością Greckich Cypryjczyków. Talat uzyskał aż 55,6\% głosów i tym samym został prezydentem już po pierwszej turze. Drugie

1 About Cyprus, Nicosia 2009, s. 81.

2 The Republic of Cyprus: An Overview, Nicosia 2011, s. 30.

3 Ibidem, s. 31.

${ }^{4}$ Zob. podrozdział 8.3 . 
miejsce zajął Derviş Eroğlu z UBP (22,73\%), natomiast trzecie reprezentujący Partię Demokratyczną Mustafa Arabacığlu $(13,22 \%)^{5}$. Wybory z 2005 roku miały wyjątkowy charakter, ponieważ po raz pierwszy w historii nie wziął w nich udziału Rauf Denktaş. Wkrótce po zakończeniu prezydentury, Denktaş wycofał się z oficjalnej działalności politycznej, ale nie z życia politycznego. Tym samym aż do swojej śmierci w styczniu 2012 roku pozostał aktywnym komentatorem wydarzeń politycznych.

Początkowo Mehmet Ali Talat cieszył się sympatią nie tylko większości Tureckich Cypryjczyków, ale także społeczności międzynarodowej. Niemniej, nie udało mu się nawiązać konstruktywnego dialogu z Tassosem Papadopulosem. Sytuacja zmieniła się dopiero w 2008 roku, gdy prezydentem Republiki Cypryjskiej został Dimitris Christofias. Obaj politycy zainaugurowali kolejną rundę rokowań. Jednakże, dwa lata później, Talat przegrał wybory i stracił pozycję lidera swojej społeczności.

Wybory z 18 kwietnia 2010 roku wygrał jego największy polityczny przeciwnik, premier Derviş Eroğlu, który uzyskał 50,38\% i został wybrany prezydentem już w pierwszej turze. Mehmet Ali Talat otrzymał 42,85\%. Wybór Eroğlu w praktyce oznaczał odejście od dotychczasowej taktyki negocjacyjnej. Nowy lider zapowiedział wprawdzie kontynuację rokowań z Greckimi Cypryjczykami, ale jego oświadczenie zostało sceptycznie przyjęte przez władze Republiki Cypryjskiej.

$Z$ kolei pierwsze po planie Annana wybory parlamentarne, przeprowadzone w 2005 roku, zakończyły się zwycięstwem Tureckiej Partii Republikańskiej (CTP), która uzyskała 44,45\% głosów. Po ich przeliczeniu z zastosowaniem metody d'Hondta, CTP przyznano 24 mandaty. Drugą siłą polityczną w TRPC stała się, podobnie jak to miało miejsce w 2003 roku, Partia Jedności Narodowej (UBP). Największa partia prawicowa otrzymała 31,71\% głosów - 19 mandatów. Z kolei Partii Demokratycznej (DP) zaufało 13,47\% (sześć mandatów), natomiast Ruchowi na Rzecz Pokoju i Demokracji (BDH) $5,84 \%$, co dało temu ugrupowaniu jeden mandat ${ }^{6}$.

W wyniku wyborów Turecka Partia Republikańska utworzyła rząd koalicyjny z Partią Demokratyczną, na którego czele stanął powtórnie Mehmet Ali Talat. Po wyborze lidera CTP na prezydenta TRPC w kwietniu 2005 roku, funkcję premiera objął Ferdi Soyer. Rząd CTP-DP przetrwał w tym kształcie do września 2006 r., gdy po przejściu kilku deputowanych z DP do CTP, Ferdi Soyer zrekonstruował gabinet wyłącznie w oparciu o członków $\mathrm{CTP}^{7}$.

Kolejne wybory, przeprowadzone 19 kwietnia 2009 roku, okazały się już sukcesem Partii Jedności Narodowej, która, po ponad pięciu latach przerwy, odzyskała władzę. UBP uzyskała ponad 44\%, co dało jej 26 mandatów i możliwość samodzielnego sformowania rządu. Zwycięstwo konserwatywnej UBP, z jej ówczesnym liderem Dervişem Eroğlu, było przejawem niepowodzenia polityki rządów CTP oraz radykalizacji poglądów wśród Tureckich Cypryjczyków. CTP uzyskała jedynie 15 mandatów ${ }^{8}$. Tym

5 Facts About Turkish Republic of Northern Cyprus, Nicosia 2008, s. 11.

6 TRNC Early General Elections Held, „Kibris” 2005, nr 1, s. 3.

7 Więcej zob. P. Osiewicz, Wybory w państwie nieuznawanym na przykładzie Tureckiej Republiki Pólnocnego Cypru, w: Czy upadek demokracji? Wymiar praktyczny, pod red. A. Stelmacha, Poznań 2007.

${ }^{8}$ In Search of A Comprehensive Settlement in Cyprus, Nicosia 2010, s. 31. 
samym deklarowana przez członków CTP polityka pojednania z Greckimi Cypryjczykami, zauważalna zwłaszcza w okresie 2008-2009, i zbliżenia z Unią Europejską zakończyła się niepowodzeniem. Wielu wyborców uznało, że rezygnacja ze starań o uzyskanie międzynarodowego uznania dla TRPC była błędem, a społeczność międzynarodowa nie dotrzymała słowa i nie zrealizowała obietnic złożonych po referendum z 2004 roku, ponieważ polityczna i gospodarcza izolacja północnego Cypru trwała nadal.

\section{Nowa runda rokowań bezpośrednich: 2008-2012}

Jak już wcześniej wspomniano, sytuacja zmieniła się diametralnie po wyborach prezydenckich w Republice Cypryjskiej w lutym 2008 roku. Urzędujący prezydent Tassos Papadopulos przegrał w drugiej turze z Dimitrisem Christofiasem, postrzeganym za zwolennika dialogu i pojednania na Cyprze. Jeszcze w trakcie kampanii wyborczej, Christofias wielokrotnie oświadczał, że jest zdecydowanym przeciwnikiem wznowienia rokowań na podstawie planu Annana. Zamiast rozwiązania narzuconego z zewnątrz, preferował porozumienie wynegocjowane przez samych Cypryjczyków. Wśród Greckich Cypryjczyków wciąż powszechne było przekonanie o brytyjsko-amerykańskim spisku, w wyniku którego powstała bardzo niekorzystna dla nich, piąta wersja planu Annana. Jednocześnie, w przeciwieństwie do Mehmeta Ali Talata, opowiadał się za swobodnym procesem negocjacyjnym, nieograniczonym żadnymi ramami czasowymi ${ }^{9}$. Niemniej, już sam zamiar otwarcia nowych negocjacji stanowił zapowiedź znaczącej zmiany w porównaniu z okresem prezydentury Tassosa Papadopulosa po 2004 roku.

Pierwszym dowodem zmiany polityki Greckich Cypryjczyków było stosunkowo szybko zorganizowane spotkanie prezydenta Christofiasa z liderem Tureckich Cypryjczyków Mehmetem Ali Talatem. 21 marca, już w trakcie pierwszego spotkania, została podjęta przełomowa decyzja o ustanowieniu sześciu grup roboczych (podział władzy, sprawy związane z członkostwem w UE, bezpieczeństwo i gwarancje, terytorium, prawo własności, zagadnienia ekonomiczne) oraz siedmiu zespołów technicznych (sprawy kryminalne, sprawy handlowe, dziedzictwo kulturowe, zarządzanie kryzysowe, kwestie humanitarne, zdrowie, środowisko), celem analizy stanowisk stron, ustalenia katalogu rozbieżności i przygotowania warunków koniecznych dla wznowienia nego$\operatorname{cjacji}^{10}$. Grupy robocze i zespoły techniczne rozpoczęły prace 18 kwietnia. W tym samym miesiącu działania podjęte przez przedstawicieli obu cypryjskich społeczności uzyskały poparcie ze strony Rady Bezpieczeństwa ONZ. Warto przy okazji podkreślić, iż ważnym sygnałem świadczącym o woli porozumienia było otwarcie kolejnego przejścia na linii zawieszenia ognia w centrum Nikozji1 ${ }^{11}$. Zburzenie barykad i zapór na

9 M. Hatay, R. Bryant, Negotiating the Cyprus Problem(s), Istanbul 2011, s. 9.

10 Agreement of 26 March 2008, www.trncpresidency.org (4.04.2008). Grupy robocze zajmuja się najważniejszymi zagadnieniami z punktu widzenia przyszłego porozumienia, natomiast zespoły techniczne koncentrują się na sprawach związanych z codziennymi kontaktami pomiędzy Greckimi i Tureckimi Cypryjczykami.

11 J. Christou, 20000 people crossed at Ledra over the weekend, „Cyprus Mail” z 8 kwietnia 2008 r. 
głównym, historycznym deptaku handlowym stolicy Lidras - jednym z symboli podziału miasta i wyspy - zakończyło kilkuletni spór i stanowiło impuls dla kontynuowania zbliżenia $^{12}$. Warto zaznaczyć, iż w okresach pomiędzy spotkaniami liderów, wszelkie sprawy związane z negocjacjami uzgadniali ich najbliżsi doradcy. Stronę grecką reprezentował były minister spraw zagranicznych Jorjos Iakowu, natomiast turecką - Özdil Nami, którego później zastąpił Kudret Özersay.

Podczas drugiego spotkania 23 maja 2008 roku obaj liderzy zadeklarowali, iż podstawą przyszłego rozwiązania kwestii cypryjskiej powinny stanowić utworzenie dwustrefowej federacji obu społeczności jako jednego podmiotu prawa międzynarodowego, wprowadzenie wspólnego obywatelstwa oraz zagwarantowanie równości politycznej Greckich Cypryjczyków i Tureckich Cypryjczyków. Jednocześnie Dimitris Christofias i Mehmet Ali Talat podkreślili potrzebę zwiększenia liczby przejść na linii zawieszenia ognia oraz wprowadzenie wybranych środków budowy zaufania ${ }^{13}$.

Na początku lipca obaj przywódcy postanowili zapoznać się z wynikami prac grup roboczych oraz zespołów technicznych. 1 lipca obie strony wyraziły zgodę na wprowadzenie wspólnego obywatelstwa oraz wspólnej podmiotowości na arenie międzynarodowej. Tym samym Mehmet Ali Talat potwierdził, że strona Tureckich Cypryjczyków jest gotowa zrezygnować $\mathrm{z}$ dążeń do uzyskania uznania dla TRPC, jeśli uda się osiagnąć kompromis w najważniejszych kwestiach i podpisać porozumienie. Ostatni przegląd wyników prac grup roboczych oraz zespołów technicznych miał miejsce 25 lipca. Wówczas podjęta została przełomowa decyzja o wznowieniu rokowań dwustronnych 3 września 2008 roku. Prezydent Republiki Cypryjskiej wezwał Tureckich Cypryjczyków oraz Turcję do przedstawienia elastycznego stanowiska oraz okazania dobrej woli w trakcie procesu negocjacyjnego. Jednocześnie Dimitris Christofias zadeklarował: „Nasze stanowisko jest rozsądne i sprawiedliwe. Jego podstawę stanowi niezmiennie wola ponownego zjednoczenia naszego państwa, naszych obywateli, naszych instytucji oraz naszej gospodarki" ${ }^{\prime 14}$.

Prezydent nieuznawanej przez społeczność międzynarodową TRPC Mehmet Ali Talat uzyskał, po raz kolejny, wyraźne poparcie polityczne ze strony władz tureckich. Dowodem tego była, między innymi, wypowiedź premiera Turcji Recepa Tayyipa Erdoğana podczas jednodniowej wizyty na Cyprze 20 lipca 2008 roku. Na kilka dni przed decydującym spotkaniem liderów obu cypryjskich społeczności szef tureckiego rządu oświadczył: „Mamy pełne zaufanie do Talata oraz członków jego zespołu negocjacyjnego. Wiemy, że są aktywnie zaangażowani w konstruktywne działania. Jako

12 To właśnie na ulicy Lidras (ang. Ledra Street, tur. Lokmaci), w 1964 roku, pojawiła się pierwsza barykada rozdzielająca Greckich Cypryjczyków i Tureckich Cypryjczyków w Nikozji. Przez lata stanowiła symbol faktycznego podziału miasta i wyspy. Na barykadzie od strony greckiej znajdował się punkt widokowy - jedyny, z którego można było bez przeszkód obserwować fragment strefy buforowej oraz kilka pierwszych budynków kontrolowanych przez Tureckich Cypryjczyków. By podkreślić wagę tego wydarzenia, 9 października 2008 roku część siedziby Komitetu Regionów (atrium) przemianowano na „Open Ledra Street”. Przemówienie z tej okazji wygłosiła Komisarz ds. Polityki Regionalnej Danuta Hübner. Zob. Danuta Hübner: 'Open Ledra Street!', http://ec.europa.eu/cyprus/news/hubner_ledra_street_en.htm (10.11.2008).

13 Latest Developments, www.mfa.gov.cy (18.10.2008).

14 J. Christou, Christofias calls on Turkey to be flexible, „Cyprus Mail” z 27 lipca 2008 r. 
rzą̧ Republiki Turcji będziemy was nadal wspierać”. Innym faktem wartym odnotowania była deklaracja zwiększenia tureckiej pomocy finansowej dla północnego Cypru z 360 milionów do 420 milionów dolarów w latach 2007-2009. Warto przy tym podkreślić, że państwo Tureckich Cypryjczyków nie mogłoby funkcjonować bez wsparcia ze strony Turcji, na co często zwracają uwagę greccy analitycy, dowodząc, iż to Turcja, a nie Tureccy Cypryjczycy są w rzeczywistości stroną w sporze.

Analiza historii dotychczasowych rokowań dowodzi, iż stanowisko Turcji w praktyce decyduje o stanowisku Turków cypryjskich oraz ich elastyczności w trakcie rozmów. Odstępstwo od tej reguły odnotowano jedynie kilkukrotnie za rządów założyciela oraz byłego prezydenta TRPC Raufa Denktaşa, który parę razy nie podporządkował się woli tureckiego rządu. Ostatni raz taka sytuacja miała miejsce w 2004 roku, gdy rząd Turcji pod przewodnictwem Recepa Tayyipa Erdoğana otwarcie zachęcał Tureckich Cypryjczyków do przyjęcia planu Annana, natomiast ówczesny prezydent TRPC odrzucał możliwość porozumienia na jego podstawie. Notabene, różnice zdań na linii Ankara-Nikozja oraz pogarszający się stan zdrowia Raufa Denktaşa zmusiły go do rezygnacji z ubiegania się o ponowną reelekcję ${ }^{15}$. Wybór Mehmeta Ali Talata, cieszącego się poparciem tureckiego rządu, pozwolił na prowadzenie bardziej koncyliacyjnej polityki względem Greckich Cypryjczyków i w praktyce przesądził o możliwości wznowienia rokowań po zmianie na stanowisku prezydenta Republiki Cypryjskiej w pierwszej połowie 2008 roku.

Otwarcie kolejnej rundy negocjacji spotkało się z bardzo życzliwym przyjęciem ze strony Komisji Europejskiej. Przewodniczący KE José Manuel Barroso oświadczył w imieniu UE: „Z radością przyjmuję wiadomość o nowej inicjatywie oraz odwadze, jaką wykazali się prezydent Dimitris Christofias oraz lider Tureckich Cypryjczyków Mehmet Ali Talat, podejmując decyzję o wznowieniu rokowań celem rozwiązania problemu cypryjskiego. W podobnym nastroju przyjąłem wiadomość o dalszych pracach nad środkami budowy zaufania. [...] Z całych sił zachęcam obie strony do współpracy oraz utrzymania takiego tempa rozmów aż do zawarcia porozumienia. Zjednoczony, zintegrowany Cypr przyniesie korzyści nie tylko samym Cypryjczykom, ale także całej Unii Europejskiej"1 ${ }^{\prime}$. Należy przy tym podkreślić, że wsparcie procesu negocjacyjnego przez Komisję Europejską nie dotyczy jedynie działań politycznych. Zawiera również, podobnie jak to miało miejsce w 2004 roku podczas głosowania nad planem Annana, deklaracje pomocy finansowej celem niwelowania dysproporcji ekonomicznych pomiędzy obiema społecznościami. Jednakże, co podkreślili analitycy Birol Yeşilada oraz Ahmet Sözen, wsparcie Unii Europejskiej dla procesu pokojowego na Cyprze na poziomie z 2004 roku nie jest już możliwe. Chociaż de iure całe terytorium Cypru zostało włączone do UE, mieszkańców wyspy w instytucjach unijnych reprezentująjedynie Greccy Cypryjczycy. Ponadto, powiązanie kwestii cypryjskiej z negocjacjami akcesyjnymi Turcji przyczyniło się do dalszego skomplikowania sytuacji politycznej

15 Rauf Denktaş pełnił nieprzerwanie funkcję prezydenta TRPC w latach 1983-2005.

16 Statement by the President of the European Commission José Manuel Barroso on the announcement of the launching of full-fledged negotiations with the aim of resolving the Cyprus problem, Brussels, 25 July 2008, http://ec.europa.eu/cyprus/news/barroso_statement_cyprus_en.htm (7.11.2008). 
na wyspie ${ }^{17}$. Przedstawiciele Tureckich Cypryjczyków zarzucają również Unii Europejskiej niewywiązanie się z obietnic złożonych tuż po referendach z kwietnia 2004 roku, zwłaszcza w kwestii stopniowego znoszenia izolacji gospodarczej północnego Cypru w ramach $\mathrm{UE}^{18}$. W tym kontekście, zdaniem strony tureckiej, bezstronność Unii Europejskiej w sporze cypryjskim budzi poważne wątpliwości. W konsekwencji można stwierdzić, iż kontynuowanie procesu pokojowego nie byłoby możliwe bez szerokiego zaangażowania ze strony ONZ. Scenariusz, w ramach którego spór zostałby uregulowany w ramach UE, nie jest póki co możliwy. Problem cypryjski wymaga tym samym stałego zaangażowania ze strony Rady Bezpieczeństwa ONZ, a tym samym w proces negocjacyjny zostały pośrednio włączone światowe mocarstwa, ze szczególnym wyróżnieniem Stanów Zjednoczonych, Federacji Rosyjskiej oraz Wielkiej Brytanii. Nie można zatem wykluczyć sytuacji, w której postęp prac celem rozwiązania kwestii cypryjskiej będzie uzależniony od jakości stosunków pomiędzy wymienionymi stałymi członkami RB ONZ.

Rozmowy, podobnie jak wszystkie prowadzone po 1974 roku, toczą się przy aktywnym wsparciu ze strony ONZ w ramach misji dobrych usług świadczonych przez SG ONZ. W trakcie spotkań Ban Ki-moona reprezentuje jego specjalny doradca do spraw Cypru Alexander Downer, natomiast na miejscu misję wspiera jego specjalna przedstawicielka Lisa Buttenheim, która w 2010 roku zastapiła na tym stanowisku Tayé-Brook Zerihouna. Negocjacje uzyskały również wsparcie ze strony wielu wpływowych polityków, w tym laureatów Nagrody Nobla - Jimmy Cartera oraz Desmonda Tutu, którzy 9 października 2008 roku odwiedzili Cypr, by zachęcić obie strony do prowadzenia konstruktywnego dialogu i trwałego uregulowania kwestii cypryjskiej ${ }^{19}$. Towarzyszył im Algierczyk Lakhdar Brahimi, który w 1989 roku przyczynił się do zakończenia wojny domowej w Libanie. Wszyscy trzej przybyli na Cypr z ramienia Grupy Starszych - forum grupującego dwunastu wpływowych i poważanych polityków, doświadczonych w rozwiązywaniu sporów i konfliktów międzynarodowych.

Ostateczny rezultat nowej rundy rokowań stanowi wielką niewiadomą. Od samego początku rozmów dostrzec było można istotne rozbieżności w ramach kluczowych obszarów negocjacyjnych. Pierwsza, zasadnicza różnica dotyczy stosunku do treści dokumentu wynegocjowanego podczas ostatniej rundy rokowań. Strona turecka, zarówno Tureccy Cypryjczycy, jak i Turcja, podtrzymują poparcie dla większości postanowień zawartych w ostatniej wersji planu Annana z marca 2004 roku, podczas gdy strona Greków cypryjskich dąży do ich rewizji ${ }^{20}$.

17 B. A. Yeşilada, A. Sözen, Emperor Has No Clothes: EU's Cyprus Challenge, w: The Cyprus Conflict: Looking Ahead, pod red. A. Sözena, Famagusta 2008, s. 103-116.

${ }_{18}$ Tej sprawie poświęcony został obszerny raport wydany przez turecką fundację TESEV w 2008 roku. Zob. A Promise to Keep: Time to End the International Isolation of the Turkish Cypriots. Foreign Policy Analysis-7, pod red. T. van den Hoogena, S. Tiryaki, M. Akgüna, Istanbul 2008. Zob. także: Z. Öniş, Turkey-EU Relations: Beyond the Current Stalemate, „Insight Turkey” 2008, Vol. 10, No. 4.

19 Carter, Tutu in Cyprus for Peace Push, „The Australian” z 10 października 2008.

20 Zob. K. Ulusoy, Turkey and the EU: Democratization, Civil-Military Relations, and the Cyprus Issue, „Insight Turkey” 2008, Vol. 10, No. 4. 
Od samego początku nowej rundy rokowań Tureckich Cypryjczyków i Greckich Cypryjczyków różniło także podejście do gwarancji bezpieczeństwa dla przyszłej federacji cypryjskiej. Mehmet Ali Talat niezmiennie podkreślał konieczność utrzymania w mocy traktatu o gwarancji z 1960 roku, pozwalającego Turcji na zachowanie prawa interwencji w przypadku pogwałcenia porządku konstytucyjnego lub zagrożenia bezpieczeństwa społeczności Tureckich Cypryjczyków. Taką możliwość odrzucał jednak prezydent Republiki Cypryjskiej, chociaż w przypadku utrzymania traktatu w mocy analogiczne prawo zachowałaby także Grecja. Podobne kontrowersje budziła również kwestia dalszego stacjonowania tureckich sił zbrojnych na wyspie po ewentualnym zawarciu porozumienia. Strona turecka niezmiennie podkreślała potrzebę zachowania kontyngentu wojskowego celem ochrony Tureckich Cypryjczyków, zwłaszcza w pierwszych latach po zawarciu porozumienia, podczas gdy Greccy Cypryjczycy nie wyrażali na to zgody. W ich przekonaniu tureckie siły zbrojne będą zawsze kojarzone przez ludność grecką z siłami okupacyjnymi i dlatego ich obecność na Cyprze byłaby szkodliwa, niepożądana oraz zaprzeczałaby idei porozumienia.

$\mathrm{W}$ trosce o spójność w ramach prowadzonej polityki zagranicznej oraz stanowiska negocjacyjnego, Republika Cypryjska nie uznała Kosowa. W 2008 roku, ówczesny minister spraw zagranicznych Markos Kyprianu oświadczył: „My również walczymy o utrzymanie integralności terytorialnej naszego państwa i chociaż wiemy, że przypadek Kosowa jest przypadkiem sui generis i nie stanowi precedensu, stanowi on pogwałcenie podstawowych zasad prawa międzynarodowego"21. Powyższa deklaracja dowodzi, iż strona Greckich Cypryjczyków konsekwentnie odcina się od wszelkich działań, które mogłyby doprowadzić do faktycznego uznania państwa Tureckich Cypryjczyków. Jednocześnie pojawia się możliwość, iż strona Tureckich Cypryjczyków będzie nadal wysuwała żądania częściowego zniesienia ograniczeń, co może doprowadzić do impasu w rokowaniach i w efekcie niepowodzenia kolejnej inicjatywy pokojowej.

Już na początku najnowszej rundy rokowań zauważalny stał się sceptycyzm niektórych czołowych polityków tureckich odnośnie końcowego sukcesu. Fakt wart podkreślenia w kontekście poprzednich inicjatyw zakończonych niepowodzeniami. Dotychczas za każdym razem, gdy jedna ze stron zaczynała przedstawiać wybrane zagadnienia jako niepodlegające jakimkolwiek negocjacjom, zaczynały się trudności ze zbliżeniem stanowisk, co prowadziło w konsekwencji do zawieszenia lub zerwania rozmów. Obawy mogą budzić, na przykład, wypowiedzi tureckiego wicepremiera Cemila Ciceka, który oświadczył, że chociaż Turcja wspiera proces pokojowy na Cyprze, nie opowiada się za porozumieniem za wszelką cenę. Jednocześnie podkreślił: „Ignorowanie faktów, a w szczególności istnienia dwóch oddzielnych państw, dwóch oddzielnych społeczności, oddzielnych demokracji i praw Turcji jako gwaranta ładu politycznego na Cyprze, uniemożliwi zawarcie porozumienia" ${ }^{22}$. Sceptycyzmu nie krył również lider Tureckich Cypryjczyków. W rozmowie z 27 października 2008 roku Mehmet Ali Talat otwarcie wyraził zaniepokojenie odnośnie dalszego rozwoju procesu negocjacyjnego.

21 J. Christou, Cyprus will never recognise Kosovo, „Cyprus Mail” z 9 kwietnia 2008 r.

22 Cicek: 'A solution is not possibile by ignoring realities of two separate states, communities, democracies and guarantorship rights' (16.10.2008). 
W tym kontekście wskazał na zbyt duże uzależnienie Dimitrisa Christofiasa od jego zaplecza politycznego oraz opinii publicznej, a także liczne przecieki do greckiej prasy, chociaż wszelkie ustalenia i propozycje formułowane podczas rozmów zostały objęte klauzulą tajności za zgodą obu stron ${ }^{23}$.

Między 31 stycznia a 2 lutego 2010 r. na Cyprze przebywał sekretarz generalny ONZ. Ban Ki-moon przybył na wyspę, by wzmocnić dialog polityczny pomiędzy liderami oraz podkreślić wsparcie ze strony ONZ. Jednocześnie wyraźnie podkreślił, iż bieżąca runda rokowań ,jest w rękach Cypryjczyków”, natomiast rola ONZ ogranicza się do świadczenia pomocy i wynika „z wyraźnego zaproszenia złożonego przez obie strony" ${ }^{24}$. Niemniej, negocjatorzy wyznaczeni przez obie społeczności wciąż zmagali się z podobnymi wyzwaniami jak ich poprzednicy w trakcie ostatnich ponad dwudziestu lat. Wkrótce zmieniła się także sytuacja polityczna na północnym Cyprze.

Wybór Dervişa Eroğlu na prezydenta nieuznawanej TRPC w kwietniu 2010 roku stanowił wyraz dezaprobaty ze strony większości Tureckich Cypryjczyków dla linii politycznej Talata. Chociaż nowy lider Tureckich Cypryjczyków zadeklarował chęć kontynuowania rokowań, prezentował inne podejście aniżeli Mehmet Ali Talat. Miał opinię polityka konserwatywnego, mniej skłonnego od ustępstw, co niewątpliwie wpłynęło na przebieg rozmów, lecz nie na ich intensywność. O ile w ciągu 18 miesięcy Talat spotkał się z Christofiasem aż 71 razy, to w ciągu dwóch lat Eroğlu spotkał się z Christofiasem również ponad 70 razy $^{25}$. Problemem stały się jednak nie tylko poglądy nowego lidera Tureckich Cypryjczyków, ale także jego polityczna przeszłość. Greccy Cypryjczycy wypominali Eroğlu, między innymi, jego zaangażowanie na rzecz uzyskania międzynarodowego uznania państwa Tureckich Cypryjczyków ${ }^{26}$.

Po czterech latach rozmów stronom nadal nie udało się osiagnnąc takiego postępu w rokowaniach, który pozwoliłby na zawarcie porozumienia. W związku z powyższym, 27 kwietnia 2012 roku w Nikozji, specjalny doradca SG ONZ Alexander Downer publicznie podsumował przebieg rokowań cypryjskich, zainaugurowanych we wrześniu 2008 roku. W trakcie przemówienia w hotelu Ledra Palace powiedział między innymi: „[...] Często powtarzamy, że ten proces negocjacyjny jest prowadzony przez Cypryjczyków i do nich należy. Warto o tym pamiętać. Warto także przypomnieć, że do tej pory udało się osiaggnąc zbliżenie stanowisk w ramach niektórych obszarów. Niemniej, jest dla mnie i dla obu liderów rzeczą oczywistą, że ostatnio negocjacje znalazły się w martwym punkcie. [...] Rola ONZ polega tylko na udzielaniu pomocy. W końcu ONZ nie może pragnąć porozumienia bardziej aniżeli dwie bezpośrednio zainteresowane strony. Jeśli liderzy Greckich i Tureckich Cypryjczyków nie potrafią znaleźć wzajemnie korzystnego modelu zjednoczonego Cypru, nie możemy ich do tego zmusič" ${ }^{27}$. W tym kontekście

\footnotetext{
23 Wywiad przeprowadzony przez autora z Mehmetem Ali Talatem w Nikozji 27 października $2008 \mathrm{r}$

24 The Republic of Cyprus: An Overview, op. cit., s. 32.

25 Archiwum autora. Wystapienie Ahmeta Sözena, Yücela Vurala i Erola Kaymaka podczas konferencji naukowej The 8th Congress on Cyprus Studies, Famagusta, 26 kwietnia 2012 r.

26 M. Hatay, R. Bryant, Negotiating the Cyprus Problem(s), op. cit., s. 7.

27 Transcript of Remarks by Special Advisor of the Secretary-General Alexander Downer following his meeting with the Secretary-General. Ledra Palace Hotel, Nicosia 27 April 2012, http://www.uncyprustalks.org/nqcontent.cfm?a_id=2466 (31.07.2012).
} 
Downer poinformował wszystkie zainteresowane strony, iż w zaistniałej sytuacji Ban Ki-moon uznał zwoływanie międzynarodowej konferencji w sprawie Cypru za środek przedwczesny i z góry skazany na niepowodzenie. Jednocześnie doradca SG ONZ do najtrudniejszych obszarów zaliczył obszary związane z wyłanianiem organów władzy wykonawczej (prezydent), gwarancjami bezpieczeństwa, prawem własności oraz obywatelstwem. Zdaniem Downera, dopiero okazanie dobrej woli oraz rzeczowe, kompromisowe propozycje w wymienionych obszarach mogłyby doprowadzić do przełomu $\mathrm{w}$ rokowaniach ${ }^{28}$. Obaj liderzy poznali stanowisko SG ONZ już wcześniej, 21 kwietnia, podczas bezpośrednich rozmów telefonicznych z Ban Ki-moonem.

Bez wątpienia treść wystapienia Alexandra Downera nie napawała optymizmem i była wynikiem chłodnej analizy sytuacji politycznej na Cyprze. Zgodnie z wcześniejszymi przewidywaniami, stało się ono także okazją do pośredniego wyrażenia dezaprobaty przez samego sekretarza generalnego ONZ Ban Ki-moona. Niemniej, warto zauważyć, iż tym razem ONZ nie popełniła błędu z poprzednich lat i nie wskazała strony, która była jej zdaniem odpowiedzialna za impas w rokowaniach. W przeszłości tego typu oświadczenia niejednokrotnie zniechęcały jedną ze stron do kontynuowania rozmów, natomiast jednocześnie drugą z nich stawiały w lepszej sytuacji i zniechęcały do dalszego uelastyczniania stanowiska. Inaczej ocenił sytuację prezydent Dimitris Christofias, który w jednym z wywiadów zarzucił Dervişovi Eroğlu zmianę wielu zobowiązań, przyjętych przez jego poprzednika Talata, co wpłynęło na zahamowanie procesu zbliżenia stanowisk stron. Jednocześnie oskarżył Turcję o celowe blokowanie negocjacji oraz nieustanne grożenie realizacją planu B, czyli starań o uzyskanie międzynarodowego uznania dla TRPC, a nawet aneksji północnej części wyspy ${ }^{29}$. Z kolei strona turecka odrzuca tego typu oskarżenia i uzasadnia swoje stanowisko potrzebą zabezpieczenia interesów Tureckich Cypryjczyków. Zarzuca także Greckim Cypryjczykom, że nie prezentują elastycznego podejścia podczas rozmów i wykorzystują członkostwo w UE do wywierania presji zarówno na społeczności tureckiej na Cyprze, jak i na władzach Turcji.

W trakcie rokowań w okresie od września 2008 do kwietnia 2012 roku odnotowano znaczący postęp w obszarach dotyczących podziału władzy, kwestii gospodarczych oraz relacji z Unią Europejską. Jednocześnie brak zmian dotyczył obszarów związanych z kwestiami własności, podziałem terytorialnym oraz gwarancji bezpieczeństwa.

Sytuacja skomplikowała się 1 lipca 2012 roku, gdy Republika Cypryjska oficjalnie objęła przewodnictwo w Radzie Unii Europejskiej. Zdaniem kierownictwa Tureckich Cypryjczyków, Republika Cypryjska przestała funkcjonować już w grudniu 1963 roku, dlatego konsekwentnie nie uznają także członkostwa Republiki Cypryjskiej w UE. $\mathrm{Z}$ tego powodu przedstawiciele tureckiej społeczności nie zamierzali kontynuować rozmów podczas cypryjskiej prezydencji.

Prezydencja Cypru wpłynęła negatywnie także na relacje Turcji z UE. Nieuregulowana kwestia cypryjska w praktyce przyczyniła się do zablokowania negocjacji akcesyjnych Turcji, zwłaszcza po zamrożeniu rokowań w ramach ośmiu obszarów w grudniu 2006 roku. Był to wynik inicjatywy Greckich Cypryjczyków oraz UE, która

28 Ibidem.

29 Interview with Demetris Christofias, ,Turkish Policy Quarterly” 2012, Vol. 11, No. 1, s. 20-21. 
w ten sposób zamierzała wymusić na Ankarze faktyczne uznanie Republiki Cypryjskiej. Rząd Turcji oświadczył jednak, że nie uznaje i nie zamierza uznać Republiki Cypryjskiej. Tym samym dyplomatyczna rywalizacja na linii Ankara-Nikozja trwała nadal. Jednym z jej przejawów było oświadczenie władz Turcji z wiosny 2012 roku, iż rozważały zawieszenie negocjacji akcesyjnych z UE w okresie cypryjskiej prezydencji.

Ostatecznie Turcja oficjalnie nie zawiesiła negocjacji członkowskich z UE, ale Tureccy Cypryjczycy nie kontynuowali rozmów z Greckimi Cypryjczykami. 4 sierpnia 2012 roku, podczas wystąpienia w Derynii z okazji 38 rocznicy zajęcia Waroszy, prezydent Dimitris Christofias oświadczył, że zaproponował stronie tureckiej otwarcie portu w Famaguście pod kontrolą UE oraz odblokowanie zamrożonych rozdziałów w ramach negocjacji akcesyjnych Turcji w zamian za zwrot i otwarcie Waroszy ${ }^{30}$. Miasto miałoby zostać zasiedlone pod kontrolą ONZ. Tym samym chciał zachęcić kierownictwo Tureckich Cypryjczyków do powrotu do stołu rokowań.

\section{Oznaki zbliżenia a nowe linie podziału}

Referenda z 2004 roku dowiodły, że podczas prowadzonych rokowań, politycy cypryjscy powinni poznać odpowiedź na następujące pytanie: Czy członkowie mojej społeczności chcą porozumienia, a jeśli tak, to na jakich warunkach? Jeżeli w przyszłości uda się wynegocjować kolejny projekt porozumienia, z pewnością i ten dokument zostanie poddany ocenie obywateli, bowiem trudno sobie wyobrazić, by Cypryjczycy zrezygnowali z tego prawa i ponownie zdali się na arbitralne decyzje SG ONZ. Ostatnie badania opinii publicznej, przeprowadzone wśród Greckich i Tureckich Cypryjczyków przez Interpeace Building Alliance w ramach projektu Cyprus 2015 w kwietniu i maju 2011 roku, wykazały, że tylko 54\% Greckich Cypryjczyków uważało Grecję za swoją ojczyznę, podczas gdy Turcję określiło w ten sposób aż 83\% Tureckich Cypryjczyków $^{31}$. 62\% Greckich Cypryjczyków (Tureccy Cypryjczycy - także 62\%) opowiadało się za możliwie najszybszym rozwiązaniem konfliktu, gdyż czas działa na niekorzyść ich społeczności. Jednocześnie 71\% (Tureccy Cypryjczycy - 77\%) zadeklarowało, że negocjatorzy powinni zadbać o interesy greckiej społeczności, nawet gdyby miało to negatywnie wpłynąć na sytuację Tureckich Cypryjczyków.

Z kolei w innym raporcie z 2011 roku respondenci po obu stronach linii Attyli musieli określić najkorzystniejszą formę rozwiązania kwestii cypryjskiej. Ponad 66\% Greckich Cypryjczyków opowiedziało się za unitarnym państwem z silną władzą centralna, a tylko $23 \%$ za utworzeniem dwustrefowej federacji. Jednocześnie Greccy Cypryjczycy odrzucili utrzymanie status quo (60\%); istnienie dwóch osobnych państw, uznanych przez społeczność międzynarodową (79\%) oraz konfederację (77\%). W przeciwieństwie do społeczności greckiej, Tureccy Cypryjczycy opowiedzieli się przede wszystkim za utrzymaniem dwóch osobnych państw, uznanych przez społeczność mię-

30 Varosha: A Bridge For Peace and Hope, „Cyprus Mail” z 4 sierpnia 2012 r.

31 Pełen raport z badań zob. Bridging the gap in intercommunal negotiations, http://cyprus2015.org/ index.php?option=com phocadownload\&view=category\&id=7\%3Apublic-opinion-poll-july-2011\&Itemid=34\&lang=en (26.07.2012). 
dzynarodową (62\%), natomiast formę federalną skłonne było zaakceptować jedynie $36 \%$. Utrzymanie status quo wybrały jedynie $24 \%$, konfederację $14 \%$, a państwo unitarne z silną władzą centralną $13 \%{ }^{32}$.

Po 2004 roku za jeden z pozytywnych procesów, służących zbliżeniu pomiędzy obiema społecznościami, należy uznać coraz szersze kontakty nie tylko na poziomie jednostek, ale także organizacji pozarządowych czy nawet władz samorządowych. Najlepszy przykład udanej współpracy pomiędzy władzami samorządowymi stanowi Nikozja $^{33}$. Z kolei budowę wzajemnego zaufania wspierają rozmaite projekty realizowane przez organizacje pozarząqowe takie jak, na przykład, Peace Reserach Institute Oslo Cyprus Centre, Peace Centre Cyprus, Hands Across the Divide czy the Cyprus Conflict Resolution Trainers Group. Ich działalność wspierają między innymi Instytut Goethego, Unia Europejska oraz UNDP. Coraz większa liczba Tureckich Cypryjczyków podejmuje pracę na południu wyspy, co także sprzyja rozwojowi wzajemnych kontaktów oraz świadomości istnienia wspólnych interesów.

Tymczasem, po czterech latach rokowań, zamiast porozumienia pojawił się kolejny sporny obszar, dotyczący zasad poszukiwania oraz ewentualnej eksploatacji złóż gazu ziemnego oraz ropy, znajdujących się w ramach wyłącznej strefy ekonomicznej Republiki Cypryjskiej. Eksploatacja złóż mogłaby stać się impulsem do zawarcia porozumienia i współpracy w tym obszarze, jednak póki co strony wolą prowadzić badania na własną rękę. Jednocześnie oskarżają się wzajemnie o bezprawny charakter prowadzonych odwiertów. 15 listopada 2011 roku amerykańska firma Noble Energy, działająca na zlecenie rządu Republiki Cypryjskiej, wydała oświadczenie, w którym poinformowała o odkryciu złóż gazu o łącznej objętości szacowanej w przedziale 3-9 bilionów metrów sześciennych. Dane te dotyczyły zaledwie jednego z trzynastu wydzielonych obszarów poszukiwań. Wystarczy wspomnieć, że 3 biliony metrów sześciennych gazu pokryłoby całkowite zapotrzebowanie mieszkańców Cypru na ten surowiec w ciągu ponad stu lat. Olbrzymia nadwyżka mogłaby zostać sprzedana. Tym samym Cypr od razu znalazł się w grupie państw potencjalnych eksporterów gazu ziemnego. Noble Energy oceniło szanse na eksploatację wspomnianych złóż na $60 \%{ }^{34}$. Współpracą z Republiką Cypryjską w dziedzinie energetycznej zainteresowany jest Izrael. W rezultacie energetyka stanowiła główny przedmiot rozmów podczas wizyty izraelskiego premiera Benjamina Netanjahu na Cyprze w lutym 2012 roku.

W odpowiedzi na działania podjęte przez stronę grecką, administracja Tureckich Cypryjczyków podjęła decyzję o rozpoczęciu poszukiwań w ramach strefy ekonomicznej znajdującej się pod efektywną kontrolą nieuznawanej TRPC. Pierwsze odwierty, prowadzone przez turecką firmę TPAO, zostały uroczyście zainaugurowane 26 kwietnia 2012 roku. Warto jednak zauważyć, że obecny podczas uroczystości turecki minister energii Taner Yıldız oświadczył: „Na świecie kwestie energetyczne są przyczynami

\footnotetext{
32 Solving the Cyprus Problem: Hopes and Fears: A Report by the 2015 Initiative, 2011, s. 19.

33 Więcej zob. P. Osiewicz, Nicosia: Conflict and Cooperation in the Divided Capital City, w: Conflict and Cooperation in Divided Cities, pod red. J. Jańczaka, Berlin 2009.

${ }^{34}$ Y. Leventis, Projecting for Control of Warm Waters: Turkey's Posturing for Hydrocarbon Hegemony in the Eastern Mediterranean, w: Cyprus Offshore Hydrocarbons: Regional Politics and Wealth Distribution, pod red. H. Faustmanna, A. Gürel, G. M. Reichberga, PRIO Cyprus Center Report 1/2012, s. 8.
} 
wojen, ale na tej wyspie przysłużą się budowie pokoju"35. Póki co jednak, polityczne deklaracje nie znajdują potwierdzenia w praktyce, gdyż władze Republiki Cypryjskiej uznały działania podjęte przez Tureckich Cypryjczyków i Turcję za bezprawne. Podobnie jak władze Tureckich Cypryjczyków, które nie wierzą w zapewnienia Greckich Cypryjczyków, iż w przyszłości będą sprawiedliwie dzielić zyski ze sprzedaży gazu. Pewną nadzieję stanowi jednak kwestia przyszłego transportu gazu ze złóż zlokalizowanych przez Noble Energy. Najtańszą opcją byłaby budowa rurociagu przez obszary kontrolowane przez Tureckich Cypryjczyków, Turcję i dalej do UE. Najdroższa, choć obecnie najbardziej prawdopodobna, jest opcja transportu skroplonego gazu LNG. Analitycy International Crisis Group, w specjalnym raporcie opublikowanym w kwietniu 2012 roku, wyrazili przekonanie, iż władze Republiki Cypryjskiej powinny zdecydować się na pierwsze rozwiązanie, które byłoby korzystniejsze nie tylko ze względów ekonomicznych, ale także politycznych. Jednocześnie wyraźnie podkreślili, że ,jeśli strony nie przestaną angażować się w działania o charakterze jednostronnym, będą narastały napięcia, incydenty staną się bardziej prawdopodobne, a interesy Turków i Greckich Cypryjczyków we wschodnim rejonie Morza Śródziemnego znajdą się na kolizyjnym kursie"36.

Inna, nowa sporna kwestia dotyczy cypryjsko-izraelskiej współpracy wojskowej. We wrześniu 2011 roku dwa izraelskie myśliwce przeleciały między Cyprem i Turcją, ignorując wezwania ze strony Tureckich Cypryjczyków. Piloci zamanifestowali w ten sposób, że znajdują się w przestrzeni lotów kontrolowanej przez Republikę Cypryjską i nie uznają poleceń północnocypryjskiej wieży kontroli lotów. Z pewnością była to kolejna odsłona w stosunkach turecko-izraelskich, które uległy znacznemu pogorszeniu po incydencie z udziałem tak zwanej Flotylli Wolności, płynącej z zaopatrzeniem dla ludności cywilnej w Strefie Gazy w maju 2010 roku. Część flotylli wyruszyła z cypryjskiego portu w Famaguście, kontrolowanego przez Tureckich Cypryjczyków. Podczas próby zajęcia tureckiego statku „Mavi Marmara”, aktywiści starli się z żołnierzami izraelskiej jednostki specjalnej. W wyniku walki śmierć poniosło wówczas dziewięciu tureckich aktywistów, a dziesięciu komandosów zostało poważnie rannych. Późniejszy incydent z udziałem izraelskich myśliwców wkrótce zyskał nowy wymiar. W styczniu 2012 roku minister obrony narodowej Izraela Ehud Barak zasugerował udostępnienie cypryjskiego lotniska wojskowego w Pafos dla izraelskich samolotów wojskowych ${ }^{37}$.

Wielkie kontrowersje budzi także kwestia budowy i sprzedaży nieruchomości na północnym Cyprze. Greccy Cypryjczycy zarzucają kierownictwu Tureckich Cypryjczyków, że te świadomie przyzwalaja, a nawet zachęcają do sprzedaży ziemi należącej do członków greckiej społeczności. Na północnym Cyprze działają dziesiątki firm budowlanych, które stawiają domy jednorodzinne, a następnie sprzedają je wraz z działkami. Ich klientami są przeważnie obcokrajowcy. Największą grupę stanowią Brytyjczycy. Zjawisko stało się masowe po 2002 roku. Tylko w 2004 roku ponad 2800

\footnotetext{
35 Turkey launches oil and gas drilling in North Cyprus, „Hürriyet Daily News” z 27 kwietnia $2012 \mathrm{r}$.

${ }^{36}$ Aphrodite's Gift: Can Cypriot Gas Power a New Dialogue?, Crisis Group Europe Report №216, 2 April 2012.

37 Y. Leventis, Projecting for Control of Warm Waters: Turkey's Posturing for Hydrocarbon Hegemony in the Eastern Mediterranean, w: Cyprus Offshore Hydrocarbons: Regional Politics and Wealth Distribution, op. cit., s. 9.
} 
obcokrajowców złożyło wnioski o pozwolenie na zakup nieruchomości na północnym Cyprze, które miały zostać pozytywnie rozpatrzone przez właściwe organy nieuznawanej TRPC. Dla porównania - w 2002 roku było ich 591, a w $2003-955^{38}$. Władze Republiki Cypryjskiej przestrzegają przed zakupem takich domów, które zostały postawione na gruncie należącym do Greckich Cypryjczyków. Poza szeroką kampanią informacyjną, wspierają także pozwy składane przez prawowitych właścicieli w cypryjskich sądach. Najgłośniejszym przypadkiem stała się sprawa z powództwa Meletiosa Apostolidisa przeciwko brytyjskiemu małżeństwu - Davidovi i Lindzie Oramom. Brytyjska para kupiła dom na północnym Cyprze, położony na gruncie należącym do Apostolidisa. W 2004 roku cypryjski sąd nakazał Oramom zburzenie domu oraz wszelkich innych zabudowań wzniesionych na ziemi Greckiego Cypryjczyka. Państwo Oram odmówili wykonania wyroku. Tym samym sprawa trafiła przed sąd brytyjski ${ }^{39}$. Co ciekawe, małżeństwo Oramów reprezentowała Cherie Blair, żona brytyjskiego premiera Tony Blaira. Władze Wielkiej Brytanii zostały za to skrytykowane przez ówczesnego prezydenta Republiki Cypryjskiej Tassosa Papadopulosa.

Ostatecznie brytyjski sąd potwierdził prawo własności Meletiosa Apostolidisa, a Oramów uznał za winnych naruszenia cudzej własności. W wyniku złożonej apelacji, sprawa trafiła przed Europejski Trybunał Sprawiedliwości. Po dwóch latach, 28 kwietnia 2009 roku, ETS wydał opinię, którą potwierdził prawo sądów brytyjskich do egzekwowania wyroków wydanych przez sądy Republiki Cypryjskiej. W rezultacie brytyjski sąd apelacyjny podtrzymał wyrok sądu pierwszej instancji. Oramowie próbowali jeszcze bezskutecznie złożyć apelację od wyroku w sądzie najwyższym Zjednoczonego Królestwa Wielkiej Brytanii i Irlandii Północnej. Ostatecznie sprawa zakończyła się w marcu 2010 roku, a Oramowie opuścili cypryjską nieruchomość. Sprawa Oramów została nagłośniona i stała się przedmiotem wielu analiz oraz publikacji naukowych. Prawnicy Greckich Cypryjczyków chcą wykorzystać precedens w innych, podobnych sprawach. Wszystkie te działania mają służyć zniechęcaniu kolejnych potencjalnych klientów z państw UE. Tymczasem strona turecka deklaruje, iż wszystkie umowy sprzedaży nieruchomości są zgodne z prawem i w niczym nie naruszają praw własności Greckich Cypryjczyków. Ponadto, Tureccy Cypryjczycy utrzymują, że sądy Republiki Cypryjskiej nie mogą wydawać wyroków w sprawach dotyczących nieruchomości zlokalizowanych w TRPC. Po pierwsze dlatego, iż w ich przekonaniu od 1963 roku nie funkcjonuje już państwo Republika Cypryjska, a po drugie, gdyż w tego typu sprawach sądami właściwymi są sądy TRPC.

\section{Wnioski}

Na podstawie przedstawionych faktów, możliwe jest określenie pięciu scenariuszy średnioterminowych. W trosce o przejrzystość, zostały one uszeregowane w kolejności od najbardziej do najmniej prawdopodobnego.

38 Legal Action Against Unlawful Exploitation of Stolen Properties in Turkish Occupied Cyprus, Nicosia 2005.

39 Buying Property in Cyprus, Nicosia 2006. 
Scenariusz pierwszy - najbardziej prawdopodobny. Strony będą kontynuowały intensywne prace oraz rokowania aż do momentu, gdy jedna z nich oficjalnie zadeklaruje, iż osiagnięcie porozumienia jest niemożliwe ze względu na zbyt dużą rozbieżność stanowisk. W rezultacie zachowane zostałoby status quo. Takim rozwiązaniem mogą być zainteresowani Greccy Cypryjczycy, którzy po odrzuceniu planu Annana w referendum w 2004 roku nadal, często niesłusznie, są obarczani odpowiedzialnością za nieuregulowanie kwestii cypryjskiej. Niektórzy przedstawiciele Tureckich Cypryjczyków podejrzewaja, że rokowania zostały wznowione przez stronę grecką tylko i wyłącznie w tym celu. Takim samym argumentem posługują się również niektórzy greccy komentatorzy, których zdaniem chociaż Tureccy Cypryjczycy biorą udział w rokowaniach, zamiast kierować się dobrą wolą czynią wszystko, by przedstawić Greckich Cypryjczyków w złym świetle, zyskać przychylność społeczności międzynarodowej i w konsekwencji doprowadzić do uznania TRPC lub nawet aneksji północnej części Cypru przez Turcję.

Scenariusz drugi - strony osiagają kompromis we wszystkich kluczowych kwestiach, co z kolei otwiera drogę do podpisania porozumienia i ostatecznego uregulowania sporu. Scenariusz bez wątpienia najbardziej pożądany, ale jednocześnie najtrudniejszy do zrealizowania. Wiele zależeć będzie od determinacji głównych negocjatorów oraz wsparcia politycznego i finansowego ze strony ONZ, Unii Europejskiej, Stanów Zjednoczonych, Wielkiej Brytanii oraz Federacji Rosyjskiej. Pogłębiona analiza wszystkich poprzednich rund rokowań w latach 1974-2012 pozwala zauważyć, iż porozumienie nie zostało zawarte nawet w sytuacjach, gdy do wejścia planu pokojowego w życie brakowało jedynie podpisów czołowych negocjatorów lub zgody większości mieszkańców wyspy, wyrażonej w referendum. Za główną przyczynę takiego stanu rzeczy należy uznać brak dobrej woli oraz wzajemny deficyt zaufania. W tym kontekście można postawić pytanie czy tylko SG ONZ mógłby świadczyć dobre usługi w konflikcie cypryjskim, gdyby niepowodzeniem zakończył się proces rokowań zainaugurowany w 2008 roku. Zdaniem Wojciecha Forysińskiego, ,obecnie nie występuje tendencja do zastępowania ONZ jako głównego mechanizmu rozwiązywania konfliktów. Plan reunifikacji będzie prawdopodobnie wynikiem procesu w ramach ONZ, na podstawie stosownej rezolucji, natomiast negocjacje będą prowadzone pod auspicjami ONZ. Chociaż ONZ musi brać pod uwagę europejskie realia, członkostwo Republiki Cypryjskiej w UE oraz negocjacje akcesyjne Turcji, niezależne ‘europejskie rozwiązanie' pozostaje jedynie elementem retoryki" ${ }^{40}$.

Trzeci scenariusz - zakończenie rozmów niepowodzeniem z inicjatywy strony greckiej i stopniowa tajwanizacja Cypru. Według Jana Asmussena, przez tajwanizacje należy rozumieć sytuację, w której ,,doszłoby do faktycznego uznania Tureckiej Republiki Północnego Cypru, bez nawiązywania stosunków dyplomatycznych" "11. Wówczas sytuacja TRPC na arenie międzynarodowej odpowiadałaby obecnej pozycji Republiki

40 W. Forysiński, The Europeanization of the Cyprus Problem: Beyond the Catalyst Effect, w: Proceedings of the Sixth International Congress on Cyprus Studies, pod red. Ü. V. Osam, Famagusta 2008, s. 135 .

41 J. Asmussen, Cyprus After the Failure of the Annan Plan, European Centre for Minority Issues Brief No. 11/2004, Flensburg 2004, s. 12. 
Chińskiej na Tajwanie. Taki scenariusz może zostać zrealizowany, jeśli władze Republiki Cypryjskiej będą konsekwentnie odmawiały zgody na zniesienie rozmaitych ograniczeń nałożonych na północny Cypr. Pierwszymi mogą być państwa członkowskie Organizacji Konferencji Islamskiej, z Pakistanem na czele. Drugie w kolejności mogą być państwa członkowskie UE, które zaczną wywierać nacisk na Republikę Cypryjską, by ta w pełni zaangażowała się w ostateczne uregulowanie sporu i nie blokowała negocjacji akcesyjnych Turcji. Uznanie będzie uzasadniane koniecznością pełnego włączenia Tureckich Cypryjczyków w proces integracji europejskiej oraz troską o rozwój gospodarczy północnego Cypru.

Czwarty scenariusz - zakłada uznanie de iure TRPC przez państwa świata pomimo sprzeciwów ze strony Greckich Cypryjczyków. W rezultacie na arenie międzynarodowej funkcjonowałyby dwa państwa cypryjskie, a podział terytorium wyspy zostałby usankcjonowany. Należy jednak podkreślić, iż nie występują obecnie żadne przesłanki pozwalające rozważać możliwość realizacji tego scenariusza. Kierownictwo Tureckich Cypryjczyków, przynajmniej oficjalnie, nie podejmuje żadnych działań, których celem miałoby być uzyskanie międzynarodowego uznania dla TRPC.

Ostatni, piąty scenariusz, jednocześnie najmniej prawdopodobny dotyczy możliwości aneksji północnego Cypru przez Turcję. Jego realizacja niechybnie nie tylko uniemożliwiłaby jakikolwiek dialog na wyspie, ale przede wszystkim doprowadziłaby do poważnego kryzysu międzynarodowego. W świetle obowiązującej konstytucji, Grecja oraz Wielka Brytania nadal pozostają państwami gwarantami. Ponadto, Republika Cypryjska mogłaby liczyć na poparcie zarówno ze strony UE, jak i Federacji Rosyjskiej. Tym samym Turcja nie zdecyduje się na taki akt, ponieważ doprowadziłby on do jej izolacji na arenie międzynarodowej.

\section{Summary}

The Cyprus issue: the course and outcomes of the 2008-2012 negotiations

The main aim of the article was the presentation of the tendencies of economic relations development of the European Union with the Russian Federation and the People's Republic of China in the conditions of globalisation. The success of the Russian political leaders in their bilateral relations with the European Union show how important, in the mutual is approaching, are the rules and effectiveness of the international system built up in the past sixty years. An objective interest of the transatlantic community is therefore to the west, for safe and prosperous Russia, was idealistic and at the same time realistic. At the same time as it is also important, that Russia and not Africa whether the Middle East, is for Europe force, with the strategic nature. In the long term, to the european economy effectively and permanently follow in globalisation processes and that term was competitive with, Russia and China must first become innovative economy. In terms of prospective it should be emphasised that the best hope for the peaceful development of the international cooperation offers the most important actors contemporary on the world stage. 